\title{
KARAKTERISTIK ORGANOLEPTIK BAKASANG JEROAN CAKALANG (Katsuwonus pelamis, Lin) SEBAGAI PANGAN TRADISIONAL MALUKU UTARA
}

\author{
(Organoleptic Characteristics of Bakasang, Skipjack Tuna (Katsuwonus pelamis, Lin) Innards, \\ as North Maluku Traditional Food)
}

\author{
Sri Purwaningsih ${ }^{1 *}$, Rahmatia Garwan², dan Joko Santoso ${ }^{1}$ \\ 1 Departemen Teknologi Hasil Perairan, Fakultas Perikanan dan Ilmu Kelautan, Institut Pertanian \\ Bogor, Bogor 16680. \\ 2 Universitas Muhammadiyah Maluku. \\ * Alamat korespondensi: Departemen Teknologi Hasil Perairan, Fakultas Perikanan dan Ilmu Kelautan, \\ Institut Pertanian Bogor, Bogor 16680. Email: sripurwa65@yahoo.co.id
}

\begin{abstract}
Bakasang is one of the traditional products of North Maluku, this product has not been studied scientifically. The purpose of this research is to know the organoleptic characteristics of bakasang to be known and accepted by public. This research was fermented using $25 \%$ of salt with duration (0, 2, 4, 6, and 8 days), and storage with duration (0,30,60, and 90 days). Bakasang's have organoleptic tested include: appearance, odor, taste and texture. Bakasang elected to compared with commercial bakasang are usually consumed by people in North Maluku. This research shown that: fermentation treatment 4 days at 0 days storage (F4PO) and fermentation bakasang 8 days at 0 days storage (F8PO) was chosen. Paired comparison test results show that bekasang tuna has the advantage of taste and smell unique because it is more preferred by panelist.
\end{abstract}

Key words: Bakasang, traditional products, fermentation, and North Maluku

\section{PENDAHULUAN}

Berdasarkan data Statistik Perikanan Tangkap Dinas Perikanan dan Kelautan Provinsi Maluku Utara (2007), produksi ikan di Kota Ternate didominasi oleh ikan cakalang sebesar $40.6 \mathrm{ribu}$ ton/tahun, teri $12.7 \mathrm{ribu}$ ton/tahun, tuna 7.9 ribu ton/tahun, tongkol 7.8 ribu ton/ tahun, dan kakap 541.40 ton/tahun. Ikan cakalang selain sebagai komoditas dalam bentuk ekspor beku, juga dimanfaatkan secara tradisional oleh masyarakat Kota Ternate. Pengolahan tradisional yang sudah umum dikenal adalah ikan asin, ikan asap dan produk fermentasi seperti kecap ikan, terasi dan bakasang. Pada umumnya proses pengolahan ikan cakalang seperti pengasapan dan penggaraman hanya memanfaatkan bagian dagingnya saja, sedangkan bagian lainnya seperti jeroan (usus, hati, jantung, paru dan telur) dimanfaatkan sebagai produk pangan tradisional seperti bakasang.

Bakasang merupakan salah satu produk fermentasi oleh mikroba fermentatif golongan bakteri asam laktat (Ijong dan Ohta 1995). Bakasang umumnya dibuat dari jeroan ikan cakalang yang merupakan golongan scombroid yang berasal dari famili Scombroidae. Jenis ikan tersebut mengandung banyak histidin bebas di dalam jaringan daging dan bagian isi perutnya (jeroan) yang dapat diubah menjadi histamin melalui dekarboksilasi dan aktivitas dari bakteri penghasil histamin (McLauchlin et al. 2005; Jiang et al. 2007).

Tidak adanya informasi mengenai karakteristik organoleptik pada produk-produk tradisional seperti bekasang, sehingga produk tradisional kurang dikenal oleh masyarakat secara luas. Untuk itu perlu dilakukan penelitian tentang karakteristik secara organoleptik dari produk tradisional hasil perikanan yaitu produk bakasang yang merupakan kekayaan pangan tradisional Indonesia.

\section{METODE}

\begin{abstract}
Alat dan Bahan
Bahan baku yang digunakan pada penelitian ini adalah jeroan (usus, hati, jantung, paru dan telur) dari ikan cakalang (Katsuwonus pelamis, Lin) yang diperoleh dari Tempat Pelelangan Ikan (TPI) Muara Angke, Jakarta Utara. Bahan pembantu yang digunakan adalah garam yodium. Alat-alat yang digunakan dalam penelitian ini adalah alat preparasi jeroan, alat untuk fermentasi, alat untuk penyimpanan bakasang, plastik polyethylene steril, wadah plastik, botol pyrex $250 \mathrm{ml}$ dan alat-alat untuk uji organoleptik.
\end{abstract}




\section{Tahapan Penelitian}

Penelitian ini dilakukan dalam tiga tahap. Tahap pertama adalah preparasi dan karakterisasi jeroan ikan cakalang. Tahap kedua adalah fermentasi jeroan menggunakan garam $25 \%$ (b/b) dengan lama fermentasi 0, 2, 4, 6, dan 8 hari. Tahap ketiga adalah penyimpanan bakasang hasil fermentasi dengan lama penyimpanan 0, 30, 60, dan 90 hari. Bakasang yang dihasilkan dari kombinasi lama fermentasi dan lama penyimpanan selanjutnya dilakukan uji organoleptik meliputi: penampakan, bau, rasa dan tekstur. Bakasang terpilih dibandingkan dengan bakasang komersial yang biasa dikonsumsi oleh masyarakat di Maluku Utara.

\section{Pengolahan dan Analisis Data}

Uji organoleptik yang dilakukan dalam penelitian produk bakasang ini meliputi uji skoring dan perbandingan pasangan. Pada uji skoring diberikan pada penilaian terhadap mutu sensorik dalam suatu jenjang mutu. Tujuan uji skoring adalah pemberian suatu nilai atau skor tertentu terhadap karakteristik mutu. Pemberian skor dapat dilakukan dengan skala yang jumlah skalanya tergantung pada tingkat kelas yang dikehandaki. Pengujian organoleptik meliputi penampakan, bau, rasa dan tektur dari bakasang dengan kisaran nilai :1 - 9 (SNI 01-2718-1996).

Pada bakasang terpilih dilakukan uji perbandingan berpasangan dengan produk komersial yang sejenis. Pada uji ini panelis melakukan penilaian melalui formulir isian yang diberikan berdasarkan skala kelebihan, yaitu lebih baik/lebih buruk. Penilaian uji perbandingan pasangan ini dari skala -3 sampai dengan +3 , dimana -3 adalah sangat buruk, -2 = lebih buruk, -1 = agak buruk, dan $0=$ tidak berbeda,+1 $=$ agak lebih baik, $+2=$ lebih baik, serta $+3=$ sangat lebih baik.

Hasil uji secara organoleptik diolah dengan uji statistik nonparametrik KruskalWallis, bila hasil uji berbeda nyata maka dilakukan uji lanjut Multiple comparassion (Steel \& Torrie, 1993).

\section{HASIL DAN PEMBAHASAN}

\section{Karakteristik Organoleptik}

Uji organoleptik terhadap suatu makanan adalah penilaian dengan menggunakan alat indera, yaitu penglihatan, pengecap, pembau, dan pendengar. Dengan uji ini dapat diketahui penerimaan terhadap suatu produk, misalnya dalam hal ini adalah produk tradisional dari Maluku Utara berupa bakasang. Adapun hasil uji organoleptik pada produk bakasang yang akan dinilai meliputi uji penampakan, bau, rasa dan tektur.

\section{Penampakan}

Penampakan merupakan parameter organoleptik yang penting karena merupakan sifat sensoris pertama dilihat oleh konsumen. Pada umumnya konsumen memilih makanan yang memiliki penampakan menarik. Hasil uji organoleptik dan nilai skor hasil penilaian panelis terhadap penampakan bakasang pada setiap kombinasi perlakuan disajikan pada Tabel 1.

Tabel 1. Nilai Rataan Penampakan Bakasang Jeroan Ikan Cakalang

\begin{tabular}{|c|c|c|c|c|}
\hline \multirow[b]{2}{*}{ Fermentasi } & \multicolumn{4}{|c|}{ Lama penyimpanan } \\
\hline & $\begin{array}{c}\text { 0 Hari } \\
\left(P_{0}\right)\end{array}$ & $\begin{array}{c}30 \text { Hari } \\
\left(P_{30}\right)\end{array}$ & $\begin{array}{c}60 \text { Hari } \\
\left(P_{60}\right)\end{array}$ & $\begin{array}{c}90 \text { Hari } \\
\left(P_{90}\right)\end{array}$ \\
\hline 2 Hari $\left(F_{2}\right)$ & $\begin{array}{c}7.83 \pm \\
0.87^{\mathrm{a}}\end{array}$ & $\begin{array}{l}7.17 \pm \\
1.02^{\text {bcd }}\end{array}$ & $\begin{array}{l}7.13 \pm \\
1.28^{\mathrm{bcd}}\end{array}$ & $\begin{array}{l}6.53 \pm \\
1.22^{\text {cde }}\end{array}$ \\
\hline 4 Hari $\left(F_{4}\right)$ & $\begin{array}{l}7.33 \pm \\
1.18^{\mathrm{abc}}\end{array}$ & $\begin{array}{l}7.07 \pm \\
1.14^{\mathrm{bcd}}\end{array}$ & $\begin{array}{l}6.63 \pm \\
1.35^{\text {cde }}\end{array}$ & $\begin{array}{c}6.07 \pm \\
1.64^{\mathrm{e}}\end{array}$ \\
\hline 6 Hari $\left(F_{6}\right)$ & $\begin{array}{l}7.47^{ \pm} \\
0.94^{\text {ab }}\end{array}$ & $\begin{array}{l}7.03^{ \pm} \\
0.93^{\text {bcd }}\end{array}$ & $\begin{array}{l}6.67 \pm \\
1.47^{\mathrm{cde}}\end{array}$ & $\begin{array}{l}6.53 \pm \\
1.22^{\text {de }}\end{array}$ \\
\hline 8 Hari $\left(F_{8}\right)$ & $\begin{array}{l}7.30 \pm \\
0.95^{\mathrm{abc}}\end{array}$ & $\begin{array}{l}6.70 \pm \\
1.21^{\text {cde }}\end{array}$ & $\begin{array}{l}6.57 \pm \\
1.43^{\text {cde }}\end{array}$ & $\begin{array}{l}6.50 \pm \\
1.53^{\text {cde }}\end{array}$ \\
\hline
\end{tabular}

Nilai tertinggi hasil penilaian panelis adalah bakasang kombinasi lama fermentasi 2 hari pada penyimpanan 0 hari $\left(\mathrm{F}_{2} \mathrm{P}_{0}\right)$ yaitu 7.83 (berwarna coklat tua, agak cemerlang, tidak ada kotoran), sedangkan nilai terendah dihasilkan oleh bakasang kombinasi lama fermentasi 4 hari pada penyimpanan 90 hari $\left(\mathrm{F}_{4} \mathrm{P}_{90}\right)$ yaitu 6.07 (berwarna coklat agak kehitaman, agak kusam, ada sedikit kotoran). Nilai tersebut menunjukkan bahwa semakin lama penyimpanan, intensitas warna bakasang semakin menurun. Hasil uji Kruskal-Wallis menunjukkan bahwa perlakuan lama fermentasi dan lama penyimpanan berpengaruh nyata terhadap tingkat kesukaan panelis terhadap penampakan bakasang. Uji lanjut Multiple comparassion menunjukkan bahwa penampakan bakasang dengan perlakuan fermentasi 2 hari pada lama penyimpanan $0\left(\mathrm{~F}_{2} \mathrm{P}_{0}\right)$ hari berbeda nyata dengan perlakuan fermentasi 2 hari pada lama penyimpanan 30 hari $\left(\mathrm{F}_{2} \mathrm{P}_{30}\right)$. Pada bakasang dengan kombinasi perlakuan $\left(\mathrm{F}_{2} \mathrm{P}_{0}\right)$ menpunyai penampakan warna coklat yang lebih tua dan cemerlang, serta tidak ada kotoran, sedangkan bakasang perlakuan $\left(\mathrm{F}_{2} \mathrm{P}_{30}\right)$ memiliki warna coklat kehitaman, agak kusam dan sedikit ada kotoran. Warna coklat yang dihasilkan diduga karena proses hidrolisis dan aktivitas mikroorganisme selama proses fermentasi dan pere- 
busan jeroan, sedangkan warna coklat kusam selama penyimpanan berkaitan dengan warna bahan bakunya yaitu coklat-kemerahan. Selain itu warna coklat yang dihasilkan juga dapat disebabkan oleh reaksi pencoklatan atau browning yang terjadi karena adanya perlakuan pemasakan terhadap jeroan yang kaya akan kandungan protein dan asam-asam amino.

\section{Bau}

Bau merupakan daya tarik tersendiri dalam menentukan rasa enak dari produk suatu makanan (Soekarto dan Hubeis 2000). Dalam hal ini bau lebih banyak dipengaruhi oleh indra pencium. Umumnya bau yang dapat diterima oleh hidung dan otak lebih banyak merupakan campuran dari 4 macam bau yaitu harum, asam, tengik dan hangus (Winarno, 1997). Hasil penilaian secara oranoleptik untuk bau secara lengkap disajikan pada Tabel 2.

Tabel 2. Nilai Rataan Bau Bakasang Jeroan Ikan Cakalang

\begin{tabular}{|c|c|c|c|c|}
\hline \multirow[b]{2}{*}{ Fermentasi } & \multicolumn{4}{|c|}{ Lama penyimpanan } \\
\hline & $\begin{array}{c}0 \text { Hari } \\
\left(P_{0}\right)\end{array}$ & $\begin{array}{c}30 \text { Hari } \\
\left(P_{30}\right)\end{array}$ & $\begin{array}{c}60 \text { Hari } \\
\left(P_{60}\right)\end{array}$ & $\begin{array}{c}90 \text { Hari } \\
\left(\mathrm{P}_{90}\right)\end{array}$ \\
\hline 2 Hari $\left(F_{2}\right)$ & $\begin{array}{l}7.77 \pm \\
0.86^{\mathrm{abc}}\end{array}$ & $\begin{array}{l}7.10 \pm \\
1.32^{\text {cdef }}\end{array}$ & $\begin{array}{l}7.43 \pm \\
1.04^{\mathrm{abc}}\end{array}$ & $\begin{array}{l}7.50 \pm \\
0.78^{\mathrm{abc}}\end{array}$ \\
\hline 4 Hari $\left(F_{4}\right)$ & $\begin{array}{l}7.87 \pm \\
0.78^{\mathrm{ab}}\end{array}$ & $\begin{array}{l}7.07 \pm \\
1.11^{\text {cdef }}\end{array}$ & $\begin{array}{c}6.73 \pm \\
1.26^{f}\end{array}$ & $\begin{array}{l}7.17 \pm \\
0.99^{\mathrm{de}}\end{array}$ \\
\hline 6 Hari $\left(F_{6}\right)$ & $\begin{array}{c}7.50 \pm \\
0.86^{\text {abcde }}\end{array}$ & $\begin{array}{l}7.20 \pm \\
1.24^{\text {cdef }}\end{array}$ & $\begin{array}{l}7.50 \pm \\
1.04^{\mathrm{ab}}\end{array}$ & $\begin{array}{l}7.40 \pm \\
1.00^{\mathrm{bc}}\end{array}$ \\
\hline 8 Hari $\left(F_{8}\right)$ & $\begin{array}{c}8.00 \pm \\
0.95^{\mathrm{a}}\end{array}$ & $\begin{array}{l}6.87 \pm \\
1.41^{\mathrm{ef}}\end{array}$ & $\begin{array}{l}7.73 \pm \\
1.11^{\mathrm{abc}}\end{array}$ & $\begin{array}{l}7.17 \pm \\
1.23^{\text {cd }}\end{array}$ \\
\hline
\end{tabular}

Hasil penilaian panelis terhadap bau bakasang berkisar antara 6.73 (harum spesifikasi bakasang ikan, agak sedikit enak) pada bakasang $F_{4} P_{60}$ sampai 8.00 (harum spesifikasi bakasang ikan, agak enak) pada bakasang $\mathrm{F}_{8} \mathrm{P}_{0}$. Nilai bau tersebut mengalami fluktuatif sesuai tingkat penilaian panelis selama penyimpanan. Hasil uji Kruskal-Wallis menunjukkan bahwa perlakuan lama fermentasi dan lama penyimpanan berpengaruh nyata terhadap tingkat kesukaan panelis terhadap bau bakasang. Hasil uji lanjut Multiple comparassion menunjukkan bahwa bau bakasang dengan perlakuan fermentasi 8 hari pada lama penyimpanan $0\left(\mathrm{~F}_{8} \mathrm{P}_{0}\right)$ hari berbeda nyata dengan perlakuan fermentasi 4 hari pada lama penyimpanan 60 hari $\left(\mathrm{F}_{4} \mathrm{P}_{60}\right)$.

Bau harum agak enak yang dihasilkan diduga pengaruh dari proses fermentasi dan pemasakan jeroan menghasilkan terbentuknya penguapan senyawa volatil dan non-volatil dengan berberat molekul rendah. Menurut Shahidi (1998) senyawa volatil yang berperan yaitu karbonil alkohol, sulfur, hidrokarbon dan bromofenol, sedangkan senyawa non-volatil yang berperan yaitu asam amino bebas, peptida, nukleotida dan basa organik dari bahan pangan. Menurut ljong dan Ohta (1995), bau seperti ikan disebabkan adanya aroma amoniak dan asam amino glutamat.

\section{Rasa}

Rasa merupakan faktor penentu daya terima konsumen terhadap produk pangan. Faktor rasa memegang peranan penting dalam pemilihan produk oleh konsumen. Rasa merupakan respon lidah terhadap rangsangan yang diberikan oleh suatu makanan. Pengindraan rasa terbagi menjadi empat rasa, yaitu manis, asin, pahit, dan asam. Konsumen akan memutuskan menerima atau menolak produk dengan empat rasa tersebut (Soekarto dan Hubeis, 2000). Adapun hasil skor penilaian dari panelis terhadap rasa disajikan pada Tabel 3.

Tabel 3. Nilai Rataan Rasa Bakasang Jeroan Ikan Cakalang

\begin{tabular}{lcccc}
\hline \multirow{2}{*}{ Fermentasi } & \multicolumn{4}{c}{ Lama penyimpanan } \\
\cline { 2 - 5 } & $\begin{array}{c}\mathbf{0 ~ H a r i} \\
\left(\mathrm{P}_{0}\right)\end{array}$ & $\begin{array}{c}\text { 30 Hari } \\
\left(\mathrm{P}_{30}\right)\end{array}$ & $\begin{array}{c}\text { 60 Hari } \\
\left(\mathrm{P}_{60}\right)\end{array}$ & $\begin{array}{c}\mathbf{9 0 ~ H a r i} \\
\left(\mathrm{P}_{90}\right)\end{array}$ \\
\hline 2 Hari $\left(\mathrm{F}_{2}\right)$ & $6.37 \pm$ & $6.27 \pm$ & $6.37 \pm$ & $5.40 \pm$ \\
& $2.14^{\mathrm{abcd}}$ & $1.70^{\mathrm{abc}}$ & $1.30^{\mathrm{abc}}$ & $2.04^{\mathrm{de}}$ \\
4 Hari $\left(\mathrm{F}_{4}\right)$ & $6.97 \pm$ & $7.03 \pm$ & $5.97 \pm$ & $\mathbf{4 . 9 7 \pm}$ \\
& $1.90^{\mathrm{a}}$ & $1.87^{\mathrm{a}}$ & $1.71^{\mathrm{de}}$ & $2.20^{\mathrm{e}}$ \\
6 Hari $\left(\mathrm{F}_{6}\right)$ & $6.80 \pm$ & $6.73 \pm$ & $6.33 \pm$ & $5.53 \pm$ \\
& $2.11^{\mathrm{a}}$ & $1.62^{\mathrm{bc}}$ & $1.71^{\mathrm{ab}}$ & $2.10^{ \pm d e}$ \\
8 Hari $\left(\mathrm{F}_{8}\right)$ & $\mathbf{7 . 1 0 \pm}$ & $6.57 \pm$ & $6.37 \pm$ & $5.17 \pm$ \\
& $1.45^{\mathrm{a}}$ & $2.11^{\mathrm{ab}}$ & $1.69^{\mathrm{bc}}$ & $2.12^{\mathrm{e}}$ \\
\hline
\end{tabular}

Rasa bakasang hasil penilaian panelis berkisar antara 4.97 (kurang enak, rasa ikan sedikit) pada bakasang $\mathrm{F}_{4} \mathrm{P}_{90}$ sampai 7.10 (agak enak, rasa asin cukup, terlalu manis) pada bakasang $\mathrm{F}_{8} \mathrm{P}_{0}$. Hasil uji Kruskal-Wallis menunjukkan bahwa perlakuan lama fermentasi dan lama penyimpanan berpengaruh nyata terhadap tingkat kesukaan panelis terhadap rasa bakasang. Hasil uji lanjut Multiple comparassion menunjukkan bahwa rasa bakasang dengan perlakuan fermentasi 8 hari pada lama penyimpanan $0\left(\mathrm{~F}_{8} \mathrm{P}_{0}\right)$ hari berbeda nyata dengan perlakuan fermentasi 4 hari pada lama penyimpanan 90 hari $\left(\mathrm{F}_{4} \mathrm{P}_{90}\right)$. Rasa yang dihasilkan berkaitan dengan penambahan garam dalam proses fermentasi, selain berfungsi sebagai pemberi cita rasa, garam juga berperan dalam seleksi mikroba yang dikehendaki utamanya golongan proteolitik dan lipolitik.

Rasa pada produk bakasang juga ditimbulkan oleh adanya pemecahan protein yang disebabkan oleh enzim proteolitik yang terdapat dalam jaringan jeroan itu sendiri atau oleh enzim yang dihasilkan oleh mikroba. Selama pemasakan menyebabkan meresapnya garam yang berfungsi sebagai pemberi citarasa. Rasa 
agak enak, enak dan rasa manis juga dipengaruhi oleh dua komponen utama yaitu peptida dan asam amino yang terdapat pada jeroan. Menurut ljong dan Ohta (1995); Winarno et al. (1993) rasa enak dipengaruhi oleh asam amino glutamat dan asam amino aspartat, sedangkan Saleha (2003) menambahkan bahwa rasa manis dipengaruhi oleh asam amino glisin, fenilalanin dan lisin.

\section{Tekstur}

Tekstur merupakan segala hal yang berhubungan dengan mekanik, rasa, sentuhan, penglihatan dan pendengaran yang meliputi penilaian terhadap kebasahan, kering, keras, halus, kasar, dan berminyak (Soekarto dan Hubeis, 2000). Penilaian tekstur makanan dapat dilakukan dengan menggunakan jari, gigi, dan langit-langit. Faktor tekstur diantaranya adalah rabaan oleh tangan, keempukan dan mudah dikunyah (Meilgaard et al., 1999). Adapun hasil skor penilaian dari panelis terhadap tekstur disajikan pada Tabel 4 .

Tabel 4. Nilai Rataan Tekstur Bakasang Jeroan Ikan Cakalang

\begin{tabular}{lcccc}
\hline \multirow{3}{*}{ Fermentasi } & \multicolumn{4}{c}{ Lama penyimpanan } \\
\cline { 2 - 5 } & $\begin{array}{c}\text { 0 Hari } \\
\left(\mathrm{P}_{0}\right)\end{array}$ & $\begin{array}{c}\text { 30 Hari } \\
\left(\mathrm{P}_{30}\right)\end{array}$ & $\begin{array}{c}\text { 60 Hari } \\
\left(\mathrm{P}_{60}\right)\end{array}$ & $\begin{array}{c}\text { 90 Hari } \\
\left(\mathrm{P}_{90}\right)\end{array}$ \\
\hline 2 Hari $\left(\mathrm{F}_{2}\right)$ & $6.37 \pm$ & $6.13 \pm$ & $5.83 \pm$ & $5.93 \pm$ \\
& $1.16^{\mathrm{a}}$ & $1.11^{\mathrm{a}}$ & $1.29^{\mathrm{a}}$ & $1.26^{\mathrm{a}}$ \\
4 Hari $\left(\mathrm{F}_{4}\right)$ & $6.43 \pm$ & $6.47 \pm$ & $5.93 \pm$ & $5.67 \pm$ \\
& $0.86^{\mathrm{a}}$ & $1.36^{\mathrm{a}}$ & $1.51^{\mathrm{a}}$ & $1.54^{\mathrm{a}}$ \\
6 Hari $\left(\mathrm{F}_{6}\right)$ & $6.43 \pm$ & $6.63 \pm$ & $6.20 \pm$ & $5.80 \pm$ \\
& $1.14^{\mathrm{a}}$ & $1.50^{\mathrm{a}}$ & $1.37^{\mathrm{a}}$ & $1.88^{\mathrm{a}}$ \\
8 Hari $\left(\mathrm{F}_{8}\right)$ & $6.47 \pm$ & $6.57 \pm$ & $6.00 \pm$ & $5.43 \pm$ \\
& $1.07^{\mathrm{a}}$ & $1.55^{\mathrm{a}}$ & $1.62^{\mathrm{a}}$ & $1.92^{\mathrm{a}}$ \\
\hline
\end{tabular}

Hasil penilaian panelis terhadap tekstur bakasang berkisar antara 5.43 (agak kental kurang homogen, agak kasar) pada bakasang $\mathrm{F}_{8} \mathrm{P}_{90}$ sampai 6.63 (kental, homogen, sedikit lembut) pada bakasang $\mathrm{F}_{6} \mathrm{P}_{30}$. Hasil tersebut menunjukkan terjadi kecenderungan penurunan nilai tekstur seiring dengan lamanya penyimpanan, artinya tekstur cenderung agak encer. Hasil uji Kruskal-Wallis menunjukkan bahwa perlakuan lama fermentasi dan lama penyimpanan tidak berpengaruh nyata terhadap tingkat kesukaan panelis terhadap bau bakasang.

Penurunan nilai tekstur terkait dengan aktivitas mikroba selama penyimpanan yang menguraikan makromolekul utamanya protein menjadi produk turunannya seperti peptida dan asam-asam amino dengan menghasilkan molekul air $\left(\mathrm{H}_{2} \mathrm{O}\right)$ (Rahayu et al., 1992; Winarno et al. 1993).

\section{Uji Perbandingan}

Uji organoleptik perbandingan pasangan dilakukan untuk mengetahui keunggulan dan kelemahan produk baru apabila dibandingkan dengan produk komersial (Rahayu, 2001). Dari penelitian ini diharapkan bahwa produk baru yang dihasilkan dapat lebih unggul atau sama karakteristik mutunya dengan produk komersial yang telah ada dipasaran, sehingga produk yang dihasilkan dapat diterima dan disukai oleh konsumen. Uji perbandingan dilakukan terhadap dua produk bakasang terpilih berdasarkan nilai skor organoleptik tertinggi. Adapun dua produk yang terpilih adalah kombinasi dari lama fermentasi 4 hari pada penyimpanan 0 hari $\left(\mathrm{F}_{4} \mathrm{P}_{0}\right)$ dan lama fermentasi 8 hari pada penyimpanan 0 hari $\left(\mathrm{F}_{8} \mathrm{P}_{0}\right)$. Sebagai pembanding adalah bakasang komersial yang diproduksi oleh pengolah tradisional di Kota Ternate, Provinsi Maluku Utara.

Hasil uji perbandingan pasangan menunjukkan bahwa dari segi penampakan lama fermentasi 4 hari pada penyimpanan 0 hari memiliki memiliki nilai rata-rata -1.07 yang berarti bakasang jeroan ikan cakalang memiliki penampakan bakasang agak kurang coklat dibandingkan dengan bakasang komersial. Pe nampakan pada bakasang dengan kombinasi lama fermentasi 8 hari pada penyimpanan 0 hari memiliki nilai rata-rata -0.73 yang berarti bakasang jeroan ikan cakalang memiliki penampakan bakasang agak kurang coklat dibandingkan dengan bakasang komersial. Hasil uji perbandingan pasangan menunjukkan bahwa dari segi bau untuk kombinasi perlakuan dari lama fermentasi 4 hari pada penyimpanan 0 hari $\left(\mathrm{F}_{4} \mathrm{P}_{0}\right)$ memiliki nilai rata-rata 1.70 yang berarti harum dan bakasang dengan kombinasi perlakuan lama fermentasi 8 hari pada penyimpanan 0 hari $\left(\mathrm{F}_{8} \mathrm{P}_{0}\right)$ memiliki nilai ratarata 1.33 yang berarti agak harum dibandingkan dengan bakasang komersial. Bakasang dengan lama fermentasi 4 hari pada penyimpanan 0 hari $\left(\mathrm{F}_{4} \mathrm{P}_{0}\right)$ dan lama fermentasi 8 hari pada penyimpanan 0 hari $\left(\mathrm{F}_{8} \mathrm{P}_{0}\right)$ memiliki nilai rasa berturut-turut adalah 1 dan 1.4 yang berarti agak enak dibandingkan dengan bakasang komersial. Hasil penilaian terhadap tekstur bakasang lama fermentasi 4 hari pada penyimpanan 0 hari $\left(F_{4} P_{0}\right)$ memiliki nilai tekstur -1.53 yang berarti kurang kental, sedangkan untuk lama fermentasi 8 hari pada penyimpanan 0 hari $\left(\mathrm{F}_{8} \mathrm{P}_{0}\right)$ memiliki nilai tekstur -0.5 yang berarti agak kurang kental dibandingkan dengan bakasang komersial.

Hasil uji pasangan menunjukkan bahwa mutu bekasang kombinasi perlakuan lama fer- 
mentasi 4 hari pada penyimpanan 0 hari $\left(\mathrm{F}_{4} \mathrm{P}_{0}\right)$ dan lama fermentasi 8 hari pada penyimpanan 0 hari $\left(\mathrm{F}_{8} \mathrm{P}_{0}\right)$ memiliki keunggulan lebih baik dari segi bau dan rasa, sedangkan kelemahannya dalam hal penampakan dan tekstur jika dibandingkan dengan produk komersial.

Hasil uji Kruskal-Wallis menunjukkan bahwa perlakuan lama fermentasi dan lama penyimpanan pada suhu ruang terhadap ketiga bakasang memberikan pengaruh yang berbeda nyata terhadap parameter bau, tetapi untuk parameter penampakan, rasa dan tekstur tidak berpengaruh nyata. Hasil uji lanjut Multiple comparassion menunjukkan bahwa bau bakasang komersial berbeda nyata dengan bau bakasang kombinasi perlakuan lama fermentasi 4 hari pada penyimpanan 0 hari $\left(\mathrm{F}_{4} \mathrm{P}_{0}\right)$ dan lama fermentasi 8 hari pada penyimpanan 0 hari $\left(\mathrm{F}_{8} \mathrm{P}_{0}\right)$.

\section{KESIMPULAN}

Nilai organoleptik bakasang hasil penelitian secara keseluruhan sampai akhir penyimpanan (90 hari) masih menunjukkan karakteristik baik meskipun terjadi penurunan. Berdasarkan hasil rata-rata nilai organoleptik terpilih dari semua perlakuan, didapatkan dua produk bakasang terpilih (terbaik) menurut penilaian panelis yaitu pada bakasang kombinasi perlakuan lama fermentasi 4 hari pada penyimpanan 0 hari $\left(\mathrm{F}_{4} \mathrm{P}_{0}\right)$ dan bakasang lama fermentasi 8 hari pada penyimpanan 0 hari $\left(\mathrm{F}_{8} \mathrm{P}_{0}\right)$. Hasil uji perbandingan pasangan menunjukkan bahwa bekasang ikan cakalang mempunyai kelebihan pada rasa dan bau khas karena lebih disukai oleh panelis.

\section{DAFTAR PUSTAKA}

[DKP] Dinas Kelautan dan Perikanan. 2007. Laporan Statistik Perikanan Tangkap. Ternate. Dinas Kelautan dan Perikanan Provinsi Maluku Utara.

Ijong FG \& Ohta Y. 1995. Amino acid composition of bakasang, a traditional fermented fish sauce from Indonesia. Journal of Microbiological Methods. 25, 236-237.

Jiang JJ, Qing XZ, Zhi WZ, \& Li YZ. 2007. Chemical and sensory changes associated Yu-lu - a tradisional Chinese fish sauce. Food Chemistry. 104: 1629-1634.
McLauchlin J, Little CL, Grant KA, \& Mithani V. 2005. Scombrotoxic fish poisoning. Journal of Public Health. 28, 61-62.

Meilgaard M, Civille GV, Carr BT. 1999. Sensory Evaluation Techniques. 3nd eds. CRC Press, Florida.

Rahayu WP, Ma'oen S, Suliantari, \& Fardiaz S. 1992. Teknologi Fermentasi Produk Perikanan. Pusat Antar Universitas Pangan dan Gizi, Institut Pertanian Bogor, Bogor.

Rahayu WP. 2001. Penuntun Praktikum Penilaian oganoleptik. Departemen Teknologi Pangan dan Gizi, Fakultas Teknologi Pertanian, Institut Pertanian Bogor, Bogor.

Saleha S. 2003. Karakterisasi fraksi gurih dari ikan asin, ikan peda dan kecap ikan [tesis]. Ilmu Pangan, Program Pascasarjana, Institut Pertanian Bogor, Bogor.

Shahidi F. 1994. Flavour of Meat and Meat Product. Autama Press, New York.

[SNI] Standardisasi Nasional Indonesia. 1992. SNI: 01-2729-1992. Ikan Segar. Badan Standardisasi Nasional, Jakarta.

. 1996. SNI: 01-2718-1996. Petis Udang. Badan Standardisasi Nasional, Jakarta.

Soekarto ST dan Hubeis M. 2000. Metodologi Penelitian Organoleptik. Petunjuk Laboratorium. Pusat Antar Universitas Pangan dan Gizi, Progran Studi Ilmu Pangan, Institut Pertanian Bogor.

Steel RGD \& Torrie JH. 1993. Prinsip dan Prosedur Statistik. Suatu Pendekatan Biometrik. Sumantri B, penerjemah. Gramedia Pustaka Umum, Jakarta.

Winarno FG, Fardiaz S, \& Fardiaz D. 1997. Indonesian Fermented Foods Lecture Presented to Regional Graduate Nutrition Course. Souteast Asia Ministers of Education Organization (SEAMEO) Bogor Agricultural University, Bogor. 